\title{
Radix Tetrastigma hemsleyani flavone inhibits proliferation, migration, and invasion of human lung carcinoma A549 cells
}

This article was published in the following Dove Press journal:

OncoTargets and Therapy

4 February 2016

Number of times this article has been viewed

\section{Liangrui Zhong' \\ Junxian Zheng ${ }^{2}$ \\ Qianqian Sun ${ }^{3}$ \\ Kemin $\mathrm{Wei}^{2}$ \\ Yijuan $\mathrm{Hu}^{2}$}

'Department of Oncology, Tongde Hospital of Zhejiang Province, Affiliated to Zhejiang Chinese Medical University, ${ }^{2}$ Department of Chinese Medicine, Zhejiang Academy of Traditional Chinese Medicine, ${ }^{3}$ Department of Chinese Medicine, Zhejiang Chinese Medical University, Hangzhou, Zhejiang, People's Republic of China
Correspondence: Yijuan Hu Department of Chinese Medicine, Zhejiang Academy of Traditional

Chinese Medicine, 132 Tianmushan Road, Hangzhou 3100 I2, Zhejiang, People's Republic of China Tel +86 57I 88849080 Email huyijuan2014@163.com
Abstract: Radix Tetrastigma hemsleyani flavone (RTHF) is widely used as a traditional herb and has detoxification and anti-inflammatory effects. In this study, we investigated the potential effects of RTHF on the growth and metastasis of human lung adenocarcinoma A549 cells and evaluated its mechanisms. A549 cells were treated with RTHF at various concentrations for different periods. In vitro Cell Counting Kit- 8 assay and colony formation methods showed that RTHF had dose- and time-dependent antiproliferation effects on A549 cells. A cell adhesion assay showed that RTHF decreased A549 cell adhesion in a dose-dependent manner. Cell invasion and migration were investigated using the Transwell assay and observed using an inverted microscope; the results showed that cell metastasis was significantly lower in the treatment group than that in the control group $(P<0.01)$. Expression of metastasis-related matrix metalloproteinases (MMPs) and tissue inhibitors of metalloproteinases (TIMPs) was detected by real-time polymerase chain reaction and Western blotting. The results showed that the expression of MMP-2, MMP-9, and TIMP-1 decreased, while that of TIMP-2 increased significantly in the RTHF group when compared with the results of the control group. These results show that RTHF exhibits antigrowth and antimetastasis activity in lung cancer A549 cells by decreasing the expression of MMP-2/-9 and TIMP-1 and increasing that of TIMP-2.

Keywords: flavone, radix Tetrastigma hemsleyani, metastasis, lung cancer

\section{Introduction}

Non-small-cell lung carcinoma is one of the leading causes of death in the People's Republic of China, and the overall poor outcome is attributed to early metastasis. A recent study showed that the mean age-adjusted 5-year survival rate for lung cancer was only $12.5 \%,{ }^{1}$ despite advances in surgery and chemotherapy. Thus, new anti-lung cancer drugs are still required. Over the past decades, traditional Chinese medicines were used for the treatment of various cancers and other diseases. Many scientists focused on the use of therapeutic drugs derived from herbs. Chinese herbs contain potential chemotherapeutic agents that may increase the survival rates and enhance the quality of a patient's life. ${ }^{2,3}$

Radix Tetrastigma hemsleyani flavone (RTHF) is extracted from the Chinese herb radix $T$. hemsleyani, which possesses detoxification, anti-inflammatory, and anticancer activities. Previous studies have demonstrated the antiproliferation and apoptosis effects of RTHF in liver, lung, stomach cancer, and leukemic cells. ${ }^{4-7}$ However, the antimetastatic activities and mechanism of RTHF are yet to be elucidated. In this study, we determined the effect of RTHF on adhesion, migration, and invasion of human lung cancer A549 cells. The possible antimetastasis mechanisms of RTHF are demonstrated in this study. 


\section{Materials and methods}

\section{Reagents and antibodies}

RTHF was obtained from Key Laboratory of New Drug Research and Development of Traditional Chinese Medicine of Zhejiang Province, People's Republic of China. Fetal bovine serum (FBS) and RPMI 1640 medium were purchased from HyClone (Logan, UT, USA). Cell Counting Kit-8 (CCK-8) was purchased from Dojindo Molecular Technologies, Inc. (Tokyo, Japan), and Transwell invasion chamber was purchased from Corning Incorporated (Corning, NY, USA). Matrigel was from BD Biosciences (San Jose, CA, USA). The antibodies to matrix metalloproteinase 2 (MMP-2), MMP-9, tissue inhibitor of metalloproteinase 1 (TIMP-1), and TIMP-2 were purchased from Cell Signaling Technology (Beverly, MA, USA).

\section{Cell line and culture}

Human lung cancer A549 cells were obtained from Zhejiang Academy of Medical Science, People's Republic of China, and cultured in RPMI 1640 medium supplemented with $10 \%(\mathrm{v} / \mathrm{v})$ heat-inactivated FBS, $100 \mathrm{U} / \mathrm{mL}$ penicillin, and $100 \mu \mathrm{g} / \mathrm{mL}$ streptomycin, incubated in a $5 \% \mathrm{CO}_{2}$ incubator at $37^{\circ} \mathrm{C}$. The cells were passaged every $2-3$ days and used at $\sim 80 \%-90 \%$ confluence. Cell lines were obtained from the Zhejiang Institute of Medical Science for Cancer Research, People's Republic of China and, thus, ethical permission was not required to use these cell lines in this study.

\section{Cell viability assay}

The effect of RTHF on A549 cell growth was examined by the CCK-8 assay following the manufacturer's protocol. Cells were seeded at a density of $5 \times 10^{3}$ cells/well in a 96-well plate. Then, the cells were treated with RTHF at various concentrations $(0 \mathrm{mg} / \mathrm{mL}, 0.5 \mathrm{mg} / \mathrm{mL}, 1 \mathrm{mg} / \mathrm{mL}, 5 \mathrm{mg} / \mathrm{mL}$, and $10 \mathrm{mg} / \mathrm{mL}$ ) for various time periods ( 24 hours, 48 hours, and 72 hours). Each concentration was repeated six times. After the exposure period, $10 \mu \mathrm{L}$ of WST- 8 was added to each well and allowed to incubate for 3 hours. Finally, the absorbance reading of each well was detected with microplate reader at $450 \mathrm{~nm}$ (RT-3001; Thermo Fisher Scientific, Waltham, MA, USA). Decrease in the absorbance indicates increased cytotoxicity. The percentage of viable cells was estimated by comparing with that of the untreated control cells.

\section{Cell colony formation assay}

A549 cells were harvested and plated $1 \times 10^{3}$ cells/well, respectively, in six-well plates. After 24 hours of incubation, the cells were treated with various concentrations of RTHF
( $0 \mathrm{mg} / \mathrm{mL}, 1 \mathrm{mg} / \mathrm{mL}, 5 \mathrm{mg} / \mathrm{mL}$, and $10 \mathrm{mg} / \mathrm{mL}$ ). Plates were incubated for 1 week. Then, the media were removed, and the cells were washed and fixed with $4 \%$ paraformaldehyde for 15 minutes followed by staining with crystal violet. Colonies with $>50$ cells were counted and photographed with a digital Olympus camera.

\section{Cell adhesion assay}

The 3-(4,5-dimethylthiazol-2yl)-2,5-diphenyltetrazolium bromide assay was performed to calculate the number of attached cells. Each well of a 96-well plate was coated with type I collagen $(10 \mu \mathrm{g} / \mathrm{mL})$ at $4^{\circ} \mathrm{C}$ overnight. After being pretreated with various concentrations of RTHF $(0 \mathrm{mg} / \mathrm{mL}$, $1 \mathrm{mg} / \mathrm{mL}, 5 \mathrm{mg} / \mathrm{mL}$, and $10 \mathrm{mg} / \mathrm{mL}$ ) for 48 hours at $37^{\circ} \mathrm{C}$, cells were seeded at a density of $1 \times 10^{5}$ cells/well and cultured for 1 hour. Unattached cells were removed by washing with phosphate-buffered saline and then attached cells were subjected to 3-(4,5-dimethylthiazol-2yl)-2,5-diphenyltetrazolium bromide assay. The absorbance of each well was determined using the microplate reader at $570 \mathrm{~nm}$.

\section{Cell invasion and migration assays}

The cell invasion assay was performed with 24-transwell chambers (Corning Incorporated) with $8 \mu \mathrm{m}$ pore size polycarbonate filter. Matrigel was applied to the top side of the polycarbonate filter. A549 cells were resuspended in serumfree medium and added to the upper chamber at a density of $2 \times 10^{4}$ cells/well in the presence and absence of various concentrations of RTHF $(0 \mathrm{mg} / \mathrm{mL}, 1 \mathrm{mg} / \mathrm{mL}, 5 \mathrm{mg} / \mathrm{mL}$, and $10 \mathrm{mg} / \mathrm{mL}$ ). Medium containing 10\% FBS was applied to the lower chamber as a chemoattractant. After incubation for 12 hours, the cells in upper chamber were removed with a cotton swab, and the invasive cells on the lower membrane surface were fixed with $4 \%$ paraformaldehyde and stained with crystal violet. The stained invasive cells were photographed and quantified under an inverted microscope (IX71; Olympus Corporation, Tokyo, Japan) from randomly chosen fields. Each experiment was carried out in triplicate. The migration assay was measured as described in the invasion assay but without the coating of Matrigel.

\section{Real-time polymerase chain reaction assay}

After the treatments, cells were harvested, and total RNA was extracted from different treated cells as described earlier with SV total RNA purification kit (Promega Corporation, Fitchburg, WI, USA). Reverse transcript reaction was performed using QuantiTect Reverse Transcription Kit (Qiagen NV, Venlo, the Netherlands). Real-time polymerase chain 
reaction was performed using QuantiFast SYBR Green PCR Kit (Qiagen NV). The expression levels of each gene were normalized against $\beta$-actin using the comparative $\mathrm{Ct}$ method and expressed as percentage of control, with the control as 1 . Sequences of primers were MMP-2 forward (5'-ACCGAGGACTATGACCGGGATAA-3'), reverse (5'-GCTCTCATACTTGTTGCCCAGGA-3'); MMP-9 forward (5'-GCCCTGGAACTCACACGACA-3'), reverse (5'-TTGGAAACTCACACGCCAGAAG-3'); TIMP-1 forward (5'-ATGCGGCCGCATGATGGC CCCCTTTGCATC-3'), reverse (5'-ATCCCGGGT CATCGGGCCCCAAGGGATC-3'); and TIMP-2 forward (5'-GTAGTGATCAGGGCCAAAG-3'), reverse (5'-TTC TCTGTGACCCAGTCCAT-3').

\section{Western blotting analysis}

A549 cells were treated with various concentrations of RTHF ( $0 \mathrm{mg} / \mathrm{mL}, 1 \mathrm{mg} / \mathrm{mL}, 5 \mathrm{mg} / \mathrm{mL}$, and $10 \mathrm{mg} / \mathrm{mL}$ ) for 48 hours, harvested, and homogenized in $200 \mu \mathrm{L}$ RIPA lysis buffer. The cells were then extracted, and the protein concentration was determined by the Lowry method. Protein lysates $(40 \mu \mathrm{g})$ from each sample were subjected to sodium dodecyl sulfate polyacrylamide gel electrophoresis on $10 \%$ acrylamide gel, and the separated proteins were transferred to a polyvinylidene fluoride membrane. After transfer, the membranes were blocked with $5 \%$ nonfat dry milk in TBS for 1 hour at room temperature, followed by incubation with primary antibodies at $4{ }^{\circ} \mathrm{C}$ overnight and secondary horseradish peroxidase-labeled antibody $(1: 2,000)$. The target proteins on the membranes were analyzed using ECL Blotting Detection Reagents.

\section{Statistical analysis}

The data were expressed as mean \pm standard deviation and were analyzed by one-way analysis of variance by using SPSS software (Version 13.0). $P<0.05$ was considered to be statistically significant.

\section{Results}

\section{Effects of RTHF on the viability of A549 cells}

A549 cell viabilities were determined using the CCK- 8 assay at $450 \mathrm{~nm}$ after incubation with RTHF $(0 \mathrm{mg} / \mathrm{mL}, 0.5 \mathrm{mg} / \mathrm{mL}$, $1 \mathrm{mg} / \mathrm{mL}, 5 \mathrm{mg} / \mathrm{mL}$, and $10 \mathrm{mg} / \mathrm{mL}$ ) for 24 hours, 48 hours, and 72 hours, as shown in Figure 1. The results showed that RTHF dramatically decreased the proliferation of A549 cells in a dose- and time-dependent manner $(P<0.01)$. The $50 \%$ inhibition concentration was $4.95 \mathrm{mg} / \mathrm{mL}$ for 48 hours.

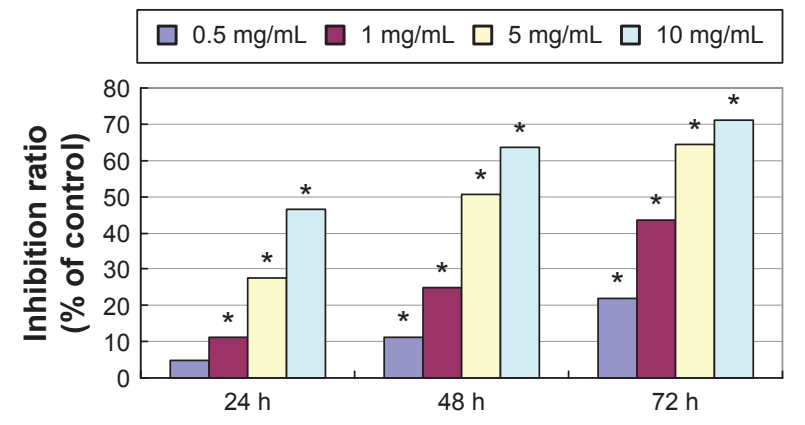

Figure I Proliferative inhibition effect of RTHF on A549 cells.

Notes: Cell survival rates were measured using CCK-8 assay. The cells were treated with various concentrations of RTHF for $24 \mathrm{~h}, 48 \mathrm{~h}$, and $72 \mathrm{~h} . \mathrm{N}=3 . * \mathrm{P}<0.0 \mathrm{l}$ vs the control group.

Abbreviations: RTHF, radix Tetrastigma hemsleyani flavone; CCK-8, Cell Counting Kit-8; h, hours.

Furthermore, the viability of A549 cells was also investigated using a colony formation assay. After treatment with RTHF ( $1 \mathrm{mg} / \mathrm{mL}, 5 \mathrm{mg} / \mathrm{mL}$, and $10 \mathrm{mg} / \mathrm{mL}$ ) for a week, the cell colonies were inhibited in a concentration-dependent manner (Figure 2).

\section{RTHF inhibits the adhesion, invasion, and migration of A549 cells}

Cell adhesion, invasion, and migration are important for cancer cell metastasis. In the cell adhesion assay, pretreated A549 cells were attached to the cell culture surface for 1 hour, and the unattached cells were washed out. As shown in Figure 3, RTHF significantly decreased the adhesion ability of A549 cells in a dose-dependent manner $(P<0.01)$. The cell invasion and migration assays were performed using the Transwell culture system. The results showed that the invasion and migration ability of cells were decreased by RTHF in a dosedependent manner. As shown in Figure 4, after treatment with $10 \mathrm{mg} / \mathrm{mL}$ of RTHF for 12 hours, invasion and migration of A549 cells were $44.73 \%$ and $31.80 \%$, respectively, compared with that observed for the control group $(P<0.01)$. These results demonstrated that RTHF significantly inhibited the metastasis of A549 lung cancer cells.

\section{Effect of RTHF on the expression of MMPs and TIMPs}

To investigate whether the metastasis inhibitory effect of RTHF was related to the suppression of MMPs and TIMPs expression, we evaluated the mRNA expression of MMP-2/-9 and TIMP-1/-2 (Figure 5) using real-time polymerase chain reaction assay and their protein level (Figure 6) by Western blot assay. The results showed that the expression of MMP-2 and MMP-9 was significantly lower in the RTHF group than in the 

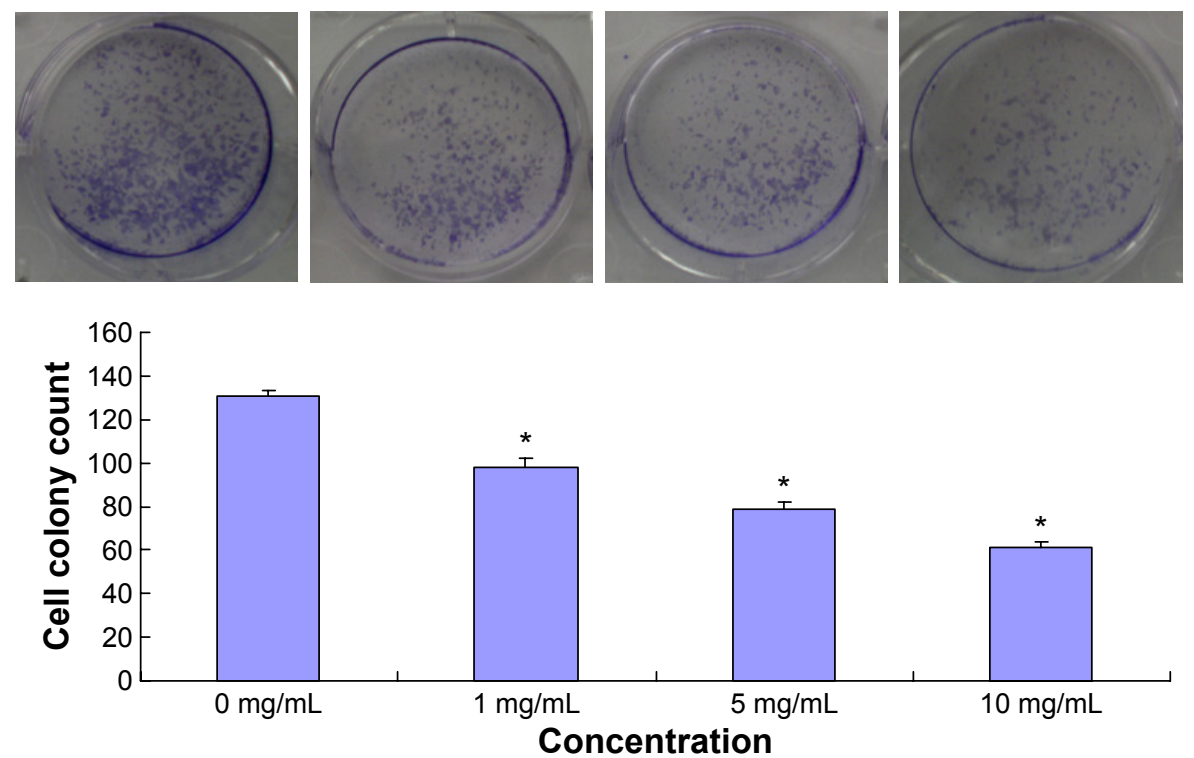

Figure 2 Effect of RTHF on cell colony formation in A549 cells.

Notes: Cells were treated with various concentrations $(0 \mathrm{mg} / \mathrm{mL}, I \mathrm{mg} / \mathrm{mL}, 5 \mathrm{mg} / \mathrm{mL}$, and $10 \mathrm{mg} / \mathrm{mL})$ of RTHF. $* P<0.01$ vs the control group. Abbreviation: RTHF, radix Tetrastigma hemsleyani flavone.

control group and decreased in a dose-dependent manner. The RTHF obviously increased the expression levels of TIMP-2 but decreased the levels of TIMP-1 in a concentration-dependent manner. The results suggested that RTHF significantly downregulated the expression of MMP-2/-9 and upregulated that of TIMP-2 in A549 cells, which may contribute to its effects on cell adhesion, migration, and invasion.

\section{Discussion}

Lung cancer is characterized by marked invasion and early metastasis, which are the major causes of both treatment failure and death. Thus, effective chemopreventive treatment for metastasis can have an impact on lung cancer mortality rates. Herbal medicine has proven to be a major source of novel pharmaceutical agents and is used worldwide. ${ }^{8-10}$ Clinical studies have shown that flavonoids may have great implications in the prevention and treatment of cancer in humans. ${ }^{11,12}$ In this study, we first explored the antimetastatic mechanism of RTHF on the invasion and migration of human lung cancer A549 cells and found that RTHF can inhibit the proliferation, adhesion, invasion, and migration of A549 cells in a dose-dependent manner in the in vitro model.

The metastatic process includes multiple events, such as cell adhesion, invasion, migration, and degradation of the extracellular matrix (ECM). It has been found to be accompanied by various physiological alterations involved in degradation of ECM, such as overexpression of proteolytic enzymes, such as MMPs and TIMPs. It is well established that many antimetastatic agents inhibit tumor growth via MMP-mediated pathway, and MMP-2 and MMP-9 were the two major proteinases secreted extracellularly by tumor cells and played critical roles in cell metastasis. ${ }^{13} \mathrm{MMP}-2$

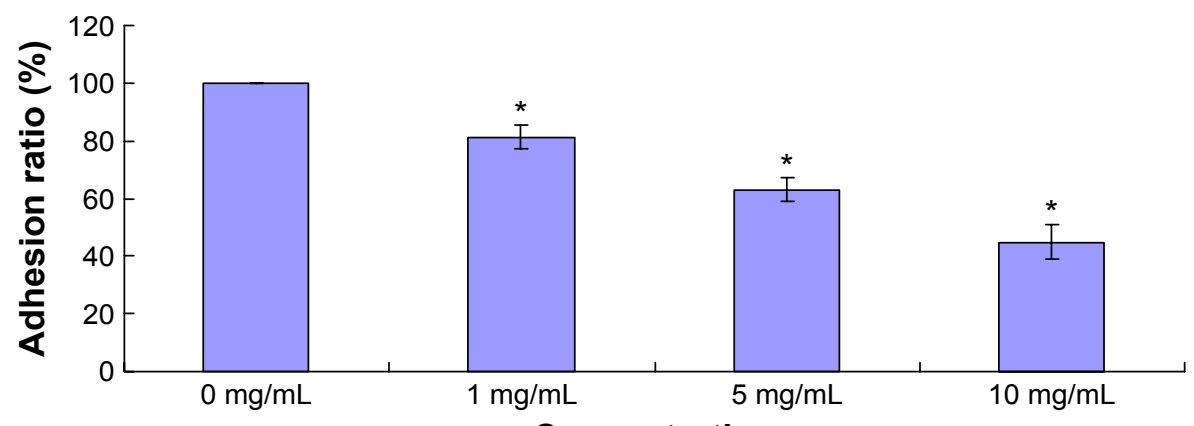

Concentration

Figure 3 Effect of RTHF on cell adhesion in A549 cells.

Notes: Cells were treated with various concentrations $(0 \mathrm{mg} / \mathrm{mL}, 1 \mathrm{mg} / \mathrm{mL}, 5 \mathrm{mg} / \mathrm{mL}$, and $10 \mathrm{mg} / \mathrm{mL})$ of RTHF. The attached cells were subjected to MTT assay with the $0 \mathrm{mg} / \mathrm{mL}$ group as $100 \%$. $* P<0.01$ vs the control group.

Abbreviations: RTHF, radix Tetrastigma hemsleyani flavone; MTT, 3-(4,5-dimethylthiazol-2yl)-2,5-diphenyltetrazolium bromide. 

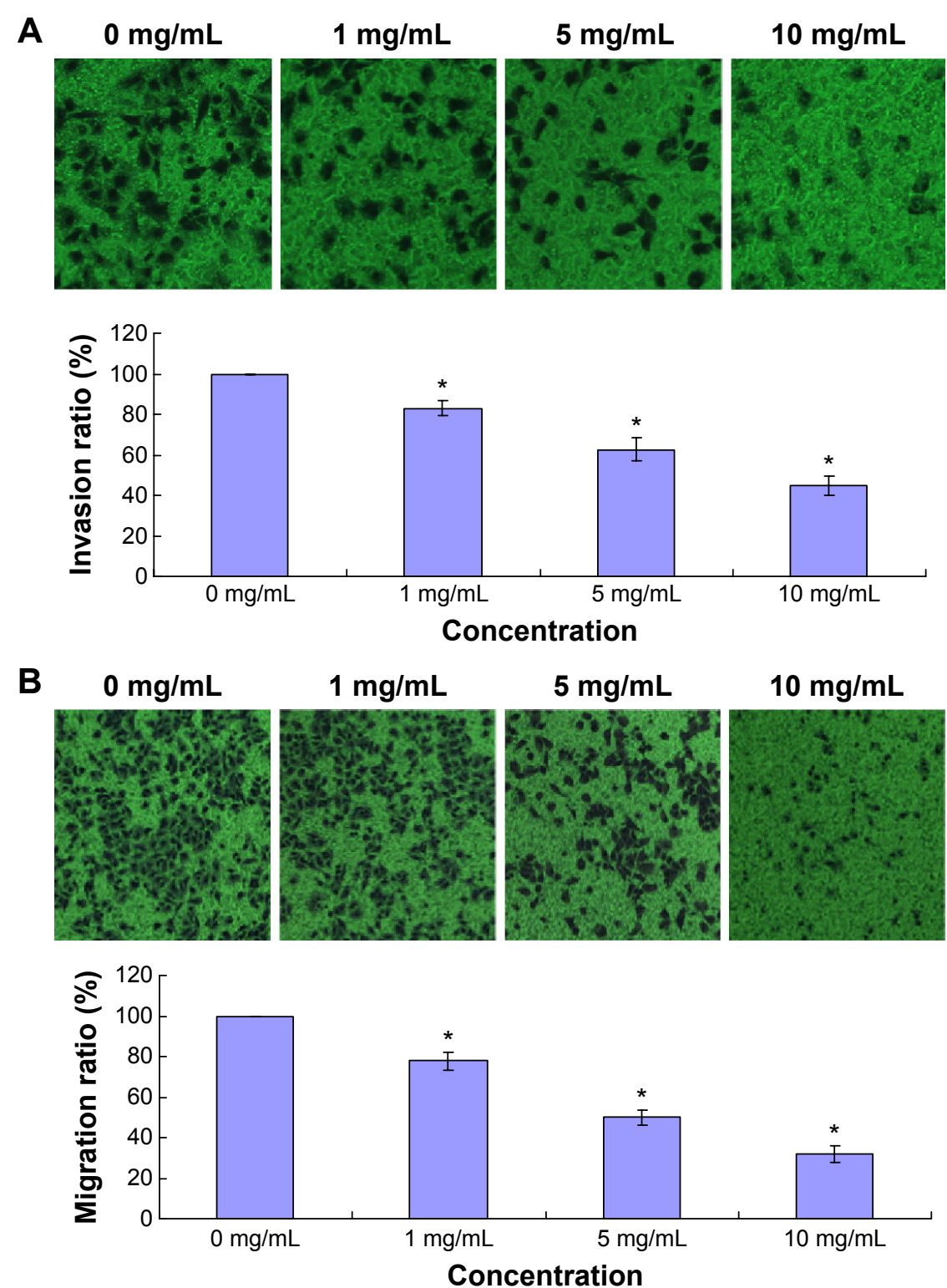

Figure 4 Effect of RTHF on cell invasion and migration in A549 cells.

Notes: Cells were treated with various concentrations $(0 \mathrm{mg} / \mathrm{mL}, I \mathrm{mg} / \mathrm{mL}, 5 \mathrm{mg} / \mathrm{mL}$, and $10 \mathrm{mg} / \mathrm{mL}$ ) of RTHF. (A) Invasion cells were quantified by counting the number of cells that invaded to the underside of the membrane under microscopy. Magnification $\times 200$. (B) Migration cells were quantified by counting the number of cells that migrated to the chamber under microscopy. Magnification $\times 100 . * P<0.01$ vs the control group.

Abbreviation: RTHF, radix Tetrastigma hemsleyani flavone.

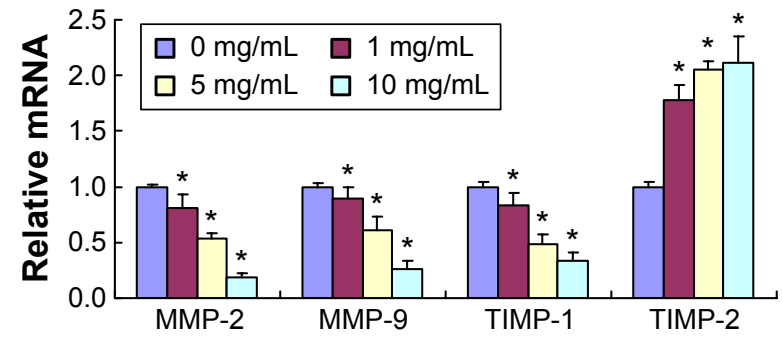

Figure 5 Validation of differentially expressed genes by real-time PCR.

Notes: Cells were treated with various concentrations $(0 \mathrm{mg} / \mathrm{mL}, 1 \mathrm{mg} / \mathrm{mL}$, $5 \mathrm{mg} / \mathrm{mL}$, and $10 \mathrm{mg} / \mathrm{mL}$ ). The expression of MMP-2, MMP-9, and TIMP-I decreased in a dose-dependent manner, whereas that of TIMP-2 increased in a dose-dependent manner. $* P<0.01$ vs the control group.

Abbreviations: PCR, polymerase chain reaction; MMP, metalloproteinase; TIMP, tissue inhibitor of metalloproteinase. and MMP-9 are vital for the degradation of ECM owing to their substrate specificity toward type IV collagen, the major component of basement membranes. . $^{14,15}$ MMP-2, an MMP involved in the breakdown of the ECM, is a biomarker for metastasis, MMP-9 plays a pivotal role in the degradation of ECM. ${ }^{16}$ Many researchers have suggested that the expression of MMP-2 and MMP-9 is closely related to cell-matrix adhesion and tumor cell invasion and metastasis. ${ }^{17,18}$

Furthermore, TIMPs regulate the activities of MMPs. TIMPs play a crucial role in ECM degradation involved in tumor cell invasion, metastasis, and angiogenesis. Moreover, MMP-2 and MMP-9 associated with tumor aggressiveness 


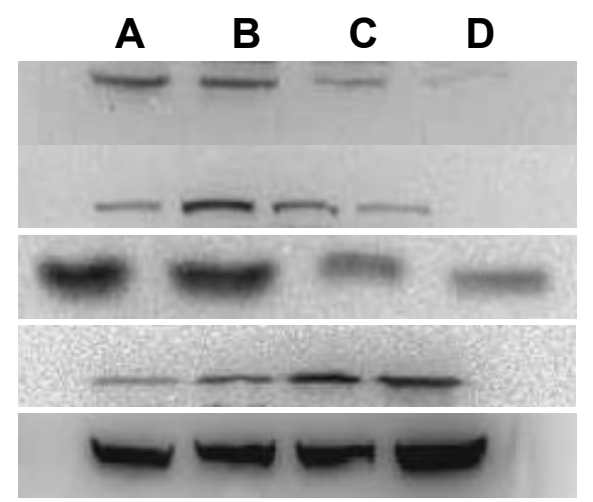

MMP-2

MMP-9

TIMP-1

TIMP-2

$\beta$-Actin

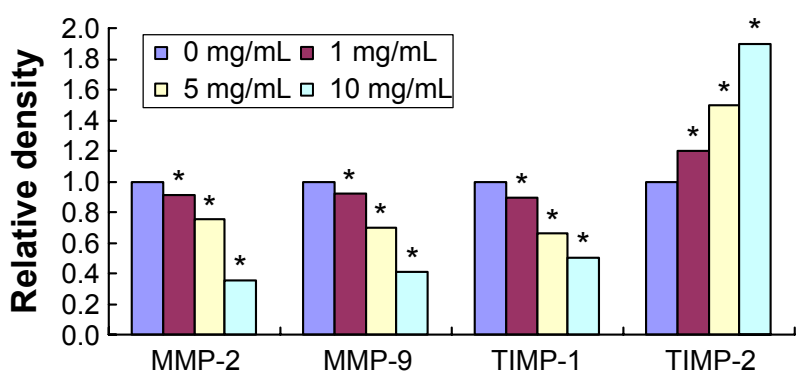

Figure 6 Effect of RTHF on the activities of MMP-2/-9 and TIMP-1/-2 in A549 cells.

Notes: Cells were treated with various concentrations $(0 \mathrm{mg} / \mathrm{mL}, I \mathrm{mg} / \mathrm{mL}, 5 \mathrm{mg} / \mathrm{mL}$, and $10 \mathrm{mg} / \mathrm{mL}$ ) of RTHF for 48 hours. (A) $0 \mathrm{mg} / \mathrm{mL}$, (B) I mg/mL, (C) $5 \mathrm{mg} / \mathrm{mL}$, and (D) $10 \mathrm{mg} / \mathrm{mL}$. Proteins were subsequently quantified by densitometric analysis with that of control being onefold. $* P=0.01$ vs the control group.

Abbreviations: RTHF, radix Tetrastigma hemsleyani flavone; MMP, metalloproteinase; TIMP, tissue inhibitor of metalloproteinase.

and poor prognosis can form complexes with TIMP-2 and TIMP-1, respectively. ${ }^{19}$ The imbalance between active MMPs and TIMPs is a crucial element involved in the remodeling of the ECM. TIMP-1 promotes cell growth and inhibits apoptosis. ${ }^{20,21}$ A correlation has been observed between cancer invasiveness and decreased TIMP-1 expression. ${ }^{22}$ Furthermore, a study has shown that TIMP-1 contributes to the development of mouse epithelial carcinogenesis. ${ }^{23}$ Many studies have found that TIMP-2 is a powerful inhibitor of MMP activity and high levels of TIMP-2 decrease tumor cell invasion. ${ }^{24,25}$ In this study, we investigated the effects of RTHF on the expression of MMPs and TIMPs proteins using Western blot analysis and found that RTHF decreased the expression levels of MMP-2 and MMP-9 in a dose-dependent manner, increased the expression of TIMP-2, and decreased the expression of TIMP-1 involved in the migration and invasion of A549 cells.

\section{Conclusion}

This study demonstrates that RTHF significantly inhibited cell proliferation, adhesion, migration, and invasion in human lung cancer A549 cells; migration and invasion is associated with the activation of MMPs and TIMPs proteins. This may be one of the molecular mechanisms by which RTHF inhibits metastasis of A549 cells.

\section{Acknowledgments}

This work was supported by the National Natural Science Foundation of China (No 81541084), the Natural Science Foundation of Zhejiang, People's Republic of China (No LQ15H290006), and the Special Fund of Science and Technology Department in Zhejiang Province for Scientific Research Institute (No 2011F10068).

\section{Disclosure}

The authors report no conflicts of interest in this work.

\section{References}

1. Kosacka M, Piesiak P, Kowal A, Gołecki M, Jankowska R. Galectin-3 and cyclin D1 expression in non-small cell lung cancer. J Exp Clin Cancer Res. 2011;30(10):101.

2. Chen HM, Lee MJ, Kuo CY, Tsai PL, Liu JY, Kao SH. Ocimum gratissimum aqueous extract induces apoptotic signalling in lung adenocarcinoma cell A549. Evid Based Complement Alternat Med. 2011; 2011:7.

3. Chang Y, Wang S, Yang C, et al. Extracts of Koelreuteria henryi Dummer induce apoptosis and autophagy by inhibiting dihydrodiol dehydrogenase, thus enhancing anticancer effects. Int $\mathrm{J} \mathrm{Mol} \mathrm{Med.}$ 2013;32(3):577-584.

4. Ding G, Zheng J, Wei K, Pu JB. Toxicological effects of the extract of Tetrastigma hemsleyanum Diels et. Gflg on hepatocellular carcinoma cell line HepG2 and primary rat hepatocytes in vitro. J Zhejiang Prev Med. 2005;17(9):1-5.

5. Zhong L, Chen X, Wei K. Radix Tetrastigma hemsleyani flavone induces apoptosis in human lung carcinoma A549 cells by modulating the MAPKs pathway. Asian Pac J Cancer Prev. 2013;14(10):5983-5987.

6. Feng Z, Ni K, He Y, et al. Experimental study on effect of Tetrastigma hemsleyanum Diels et Gilg flavone on inducing apoptosis of SGC-7901 cell line in vitro. Chin J Clin Pharmacol Ther. 2006;11(6):669-672.

7. Xu C, Wu P, Meng J, et al. Inhibitory effect on proliferation of K562 cell line by extract from Tetrastigma hemsleyanum diels et. Gilg. Chin $J$ Health Lab Tech. 2010;20(11):2801-2803.

8. Cheung F, Wang X, Wang N, et al. Chinese medicines as an adjuvant therapy for unresectable hepatocellular carcinoma during transarterial chemoembolization: a meta-analysis of randomized controlled trials. Evid Based Complement Alternat Med. 2013;2013:25.

9. De Luca V, Salim V, Atsumi SM, Yu F. Mining the biodiversity of plants: a revolution in the making. Science. 2012;336(6089):1658-1661.

10. Mondal S, Bandyopadhyay S, Ghosh MK, Mukhopadhyay S, Roy S, Mandal C. Natural products: promising resources for cancer drug discovery. Anticancer Agents Med Chem. 2012;12(1):49-75.

11. Knekt P, Järvinen R, Seppänen R, et al. Dietary flavonoids and the risk of lung cancer and other malignant neoplasms. Am J Epidemiol. 1997; 146(3):223-230.

12. Le Marchand L. Cancer preventive effects of flavonoids-a review. Biomed Pharmacother. 2002;56(6):296-301.

13. $\mathrm{Lu} \mathrm{Z,} \mathrm{Lu} \mathrm{N,} \mathrm{Li} \mathrm{C,} \mathrm{et} \mathrm{al.} \mathrm{Oroxylin} \mathrm{A} \mathrm{inhibits} \mathrm{matrix} \mathrm{metalloproteinase-}$ $2 / 9$ expression and activation by up-regulating tissue inhibitor of metalloproteinase-2 and suppressing the ERK1/2 signaling pathway. Toxicol Lett. 2012;209(3):211-220.

14. Hua H, Li M, Luo T, Yin Y, Jiang Y. Matrix metalloproteinases in tumorigenesis: an evolving paradigm. Cell Mol Life Sci. 2011;68(23): 3853-3868. 
15. Roomi MW, Monterrey JC, Kalinovsky T, Niedzwiecki A, Rath M. Modulation of MMP-2 and MMP-9 by cytokines, mitogens and inhibitors in lung cancer and malignant mesothelioma cell lines. Oncol Rep. 2009;22(6):1283-1291.

16. Lockwood CJ, Oner C, Uz YH, et al. Matrix metalloproteinase9 (MMP9) expression in preeclamptic decidua and MMP9 induction by tumor necrosis factor alpha and interleukin 1 beta in human first trimester decidual cells. Biol Reprod. 2008;78(6):1064-1072.

17. Park JK, Park SH, So K, Bae IH, Yoo YD, Um HD. ICAM-3 enhances the migratory and invasive potential of human non-small cell lung cancer cells by inducing MMP-2 and MMP-9 via Akt and CREB. Int J Oncol. 2010;36(1):181-192.

18. Hung WC, Tseng WL, Shiea J, Chang HC. Skp2 overexpression increases the expression of MMP-2 and MMP-9 and invasion of lung cancer cells. Cancer Lett. 2010;288(2):156-161.

19. Joo YE, Seo YH, Lee WS, et al. Expression of tissue inhibitors of metalloproteinases (TIMPs) in hepatocellular carcinoma. Korean J Intern Med. 2000;15(3):171-178.

20. Hayakawa T, Yamashita K, Tanzawa K, Uchijima E, Iwata K. Growthpromoting activity of tissue inhibitor of metalloproteinases-1 (TIMP-1) for a wide range of cells. A possible new growth factor in serum. FEBS Lett. 1992;298(1):29-32.
21. Li G, Fridman R, Kim HR. Tissue inhibitor of metalloproteinase-1 inhibits apoptosis of human breast epithelial cells. Cancer Res. 1999; 59(24):6267-6275.

22. Ramer R, Hinz B. Inhibition of cancer cell invasion by cannabinoids via increased expression of tissue inhibitor of matrix metalloproteinases- 1 . J Natl Cancer Inst. 2008;100(1):59-69.

23. Rhee JS, Diaz R, Korets L, Hodgson JG, Coussens LM. TIMP-1 alters susceptibility to carcinogenesis. Cancer Res. 2004;64(3):952-961.

24. Kim MH, Bodenstine TM, Sumerel LA, Rivera AA, Baker AH, Douglas JT. Tissue inhibitor of metalloproteinases-2 improves antitumor efficacy of a replicating adenovirus in vivo. Cancer Biol Ther. 2006;5(12):1647-1653.

25. Simeone AM, McMurtry V, Nieves-Alicea R, et al. TIMP-2 mediates the anti-invasive effects of the nitric oxide-releasing prodrug JS-K in breast cancer cells. Breast Cancer Res. 2008;10(3):R44.

\section{Publish your work in this journal}

OncoTargets and Therapy is an international, peer-reviewed, open access journal focusing on the pathological basis of all cancers, potential targets for therapy and treatment protocols employed to improve the management of cancer patients. The journal also focuses on the impact of management programs and new therapeutic agents and protocols on

\section{Dovepress}

patient perspectives such as quality of life, adherence and satisfaction. The manuscript management system is completely online and includes a very quick and fair peer-review system, which is all easy to use. Visit http://www.dovepress.com/testimonials.php to read real quotes from published authors. 